\title{
Consumer Protection Against Forced Withdrawal By Leasing Parties In Fiduciary Guarantee
}

\author{
Hernando Ariawan*) and Maryanto**)
}

*) Civil servants at the Central Java High Court, E-mail: hernandoariawan@yahoo.com

**) Faculty of Law Universitas Islam Sultan Agung (UNISSULA) Semarang

\begin{abstract}
The purpose of this research is to analyze consumer protection against forced withdrawals by leasing parties in fiduciary guarantees, constraints on consumer protection against forced withdrawals by leasing parties in fiduciary guarantees, and analyze consumer protection against forced withdrawals by leasing parties in fiduciary guarantees in the future. This study uses a sociological juridical approach, with analytical descriptive research methods. The data used are primary and secondary data which will be analyzed qualitatively. The research problem was analyzed using the theory of justice. The results of the study concluded that forced withdrawals were made to the debtor both physically and mentally due to the lack of heeding of the wishes of the leasing party. When the action that has a criminal threat is carried out by leasing, then there is no word for criminal abolition for them, except for certain reasons. The first party should use legal channels, namely through the courts in resolving the problem of default by the second party, so that there is permanent power in confiscation of goods against debtors in the event of bad credit. The use of Fiduciary Guarantees still has several obstacles, including: 1). Fiduciary Guarantee Registration. 2). Guaranteed vehicle withdrawals. 3). Elimination of Fiduciary Guarantee after the debt has been repaid. Consumer protection against forced withdrawals in fiduciary guarantees in the future should continue to be consistent with Act No. 8 of 1999 concerning Consumer Protection (UUPK). The enactment of this law provides hope for the people of Indonesia, to obtain protection for losses suffered by transactions of goods and services. UUPK guarantees legal certainty for consumers.

Keywords: Consumer Protection; Forced Withdrawal; Fiduciary.
\end{abstract}

\section{Introduction}

For modern countries like Indonesia, the desire to effectively guarantee the rights of citizens and regulate the orderly state administration has encouraged every country to adopt constitutionalism. ${ }^{1}$ The Indonesian state in the 1945 Constitution adheres to a welfare state, in accordance with the teachings of the welfare state, which is a concrete form of transitioning the principle of staatsonthounding, which limits the role of the state and government to interfere in the economic and social life of the community, to become staatsbemoeinis who requires the state and government to be actively involved in the economic and social life of the community, as a step to realize general welfare, in addition to maintaining order and security (rust en ordef).

\footnotetext{
${ }^{1}$ Adhe I smail A, "Constitutionalism Concept in Implementation of Indonesian State Administration". Jurnal Daulat Hukum Volume 4 Issue 2, June 2021 ISSN: 2614-560X.
} 
On the other hand, the debtor may not be willing to accept collateral in the form of a pledge, if the goods consist of a motor vehicle, therefore the debtor must bear the burden of providing a place for storing the goods. If the debtor asks for collateral in the form of mortgage or mortgage, this may not be fulfilled by the debtor, because he does not own land. Article 1338 of the Civil Code as the legal basis for the existence of "freedom of contract" opens the possibility for that, with the time limit of the agreement not contradicting the law, public order, morality. On that basis, an agreement based on the transfer of ownership of an object as collateral is an agreement to provide guarantees. The debtor (creditor) becomes the owner of the object as such, in essence, has a stronger position than a pawn holder. If the debtor pays off the debt, then the property of the object is still transferred back to the owner of the debtor's object and the debtor is to return the object to the debtor. Therefore, in order to meet these needs and to provide legal certainty to interested parties, Act No. 42 of 1999 concerning Fiduciary Guarantees was enacted which was promulgated on September 30,1999 and published in the State Gazette of the Republic of Indonesia of 1999 Number 168 which was formulated as the transfer of property rights on the basis of trust.

In connection with this guarantee, what must be done by the fiduciary recipient (creditor) if the fiduciary giver (debtor) neglects his obligations or defaults in the form of failure of the fiduciary giver (debtor) to fulfill his obligations when the debt repayment is ripe to be billed, then in such an event, the fiduciary recipient (creditor) can carry out the execution of the fiduciary guarantee object. ${ }^{2}$

In the traffic law agreement, there are at least two parties who are bound by the legal relationship, namely the creditor and the debtor.

Each party has rights and obligations born of the legal relationship, namely achievement and counter-achievement, giving, doing and not doing something, or by law it is called onderwerp object, while in the Anglo Saxon book, achievement is known as the term "consideration". ${ }^{3}$

A criminal act is an act that is prohibited by a statutory regulation, where the prohibition is accompanied by the threat of sanctions in the form of certain crimes for anyone who violates the prohibition. The settlement of criminal cases is carried out through the evidentiary process, namely the prosecution process which is carried out directly in an experiment. ${ }^{4}$ In judicial practice, the process always begins with an arrest, detention, then being prosecuted by the public prosecutor, which ends with a judge's decision. ${ }^{5}$

To prevent losses for finance companies, order and smooth payments need to be guaranteed, and given that credit agreements require a certain amount of money and many consumers are negligent in making them, all payments need to

\footnotetext{
2Ibid, p. 319

${ }^{3}$ Zainal Asikin, 2001, Hukum Kepailitan \& Penundaan Pembayaran Di Indonesia, Raja Grafindo. Jakarta, p.23.

${ }^{4}$ Ardito, Y P, Umar Ma'ruf and Aryani Witasari. "Implementation of Criminal Action Prosecution Online in Realizing Principle of Fast Prosecution, Simple \& Low Cost", Jurnal Daulat Hukum, Volume 4 Issue 2, June 2021 ISSN: 2614-560X.

${ }^{5}$ Feri, S W, and Arpangi. "Settlement Policy of Criminal Actions which Performed by Children through Penal Mediation". Jurnal Daulat Hukum Volume 4 Issue 2, June 2021 ISSN: 2614-560X.
} 
be guaranteed.6In the practice of law, often a debtor (debt) is caused by a forced situation (overmach) unable to fulfill his obligations for achievement. Thus, in the world of commerce, if the debtor is unable or unable to pay his debts to the creditor, then a solution has been prepared to solve the problem, which is known as a "bankruptcy" or "delayed payment" institution. ${ }^{7}$

The police is a subsystem in the criminal justice system that is sufficient to determine the success and work of the entire system in providing services to the public. $^{8}$ In general, execution is the implementation or decision of the court or deed, then the decision to settle the obligations of the creditor through the sale of certain objects belonging to the debtor.

The first party should use legal channels, namely through the courts in resolving the problem of default by the second party, so that there is permanent power in confiscation of goods against debtors in the event of bad credit. It has also been regulated in civil law that every agreement will result in an engagement. An engagement essentially has a legal relationship between two (2) or more people. An engagement is a legal relationship between two people/two parties based on how one party has the right to demand something from the other party, the other party is also obliged to fulfill that claim. ${ }^{9}$

From the explanation above, it can be stated that the leasing company through debt collectors is assigned to confiscate or confiscate the motorized vehicle that is credited. In response to the withdrawal of collateral by the leasing party in the execution of fiduciary guarantees and to avoid a legal vacuum, the National Police Chief's Perkap No. 8 of 2011 which specifically regulates the procedures for the execution of fiduciary objects is the basis for the execution of fiduciary guarantees. However, in this case for the process of efficiency and effectiveness in securing the goods resulting from the fiduciary guarantee, often in this case the creditor carries out the execution of the goods resulting from the fiduciary itself. In the event that there will certainly be a situation that needs attention if the debtor does not want to hand over the fiduciary goods for various reasons,

The purpose of this study is to determine consumer protection against forced withdrawals by leasing parties in fiduciary guarantees, to determine the constraints of consumer protection against forced withdrawals by leasing parties in fiduciary guarantees, and to determine consumer protection against forced withdrawals by leasing parties in fiduciary guarantees in future.

\section{Research Methods}

\footnotetext{
${ }^{6}$ Angga K and Aryani Witasari. "Law Enforcement on Fiducian Security Objects Due to Withdrawal of Fiducia Security Objects". Law Development Journal ISSN : 2747-2604 Volume 3 Issue 1, March 2021, (38-43).

7 Interview with Police Commissioner Dwi Edi Purnomo, SH, MH, Head of the Central Java Police Ditresmsus Unit, on 28 June 2021 at 10.00 WIB.

${ }^{8}$ Nurfita A T, Sri Endah Wahyuningsih and Arpangi. "The Police Role in Investigating the Crime of Child Murder as a Result of Infidelity Relationships". Law Development Journal ISSN : 2747-2604 Volume 3 Issue 1, March 2021, (86 - 92).

${ }^{9}$ Lukman Santoso, 2012, Hukum Perjanjian Kontrak, ed. I, Cakrawala, Yogyakarta, p.8.
} 
The approach method used in this study uses a sociological juridical method, namely in addition to using legal principles and principles in reviewing, viewing, and analyzing problems, as they are, ${ }^{10}$ which in this case relates to consumer protection against forced withdrawals by leasing parties in fiduciary guarantees. The specifications in this study are analytical descriptive. Descriptive research is a research method that is intended to systematically and accurately describe the facts and characteristics of the research field.

Sources of data used in this study are primary, secondary, and tertiary data sources. Primary data sources are objects that are observed directly in the field and interviewed informants. Primary legal materials consist of: State Act No. 42 of 1999 concerning Fiduciary Guarantees and Act No. 8 of 1999 concerning Consumer Protection. Tertiary legal materials consist of dictionaries, encyclopedias.

The data collection method used to obtain data that has a relationship with the object of research is interviews with resource persons and document review, while the data analysis method used is qualitative data analysis in this study including data reduction, data presentation and conclusions/verification.

\section{Result and Discussion}

\subsection{Consumer Protection Against Forced Withdrawals by Lessors Under Fiduciary Guarantees}

Consumer Protection is all efforts that guarantee legal certainty to provide protection to consumers. Consumers are every person who uses goods and/or services available in the community, both for the benefit of themselves, their families, other people, and other living creatures and not for trading.

In essence, there are two important legal instruments that form the basis of consumer protection policies in Indonesia, namely: First, the 1945 Constitution, as the source of all sources of law in Indonesia, mandates that national development aims to create a just and prosperous society. The goal of national development is realized through a democratic economic development system so that it is able to grow and develop a world that produces goods and services suitable for consumption by the community. Second, Act No. 8 of 1999 concerning Consumer Protection (UUPK). The enactment of this law provides hope for the Indonesian people to obtain protection for losses suffered by transactions of goods and services. UUPK guarantees legal certainty for consumers.

In this case, criminal liability by leasing either before or after making a forced withdrawal is the responsibility of the company even though most of the forced withdrawals use third party media/intermediaries such as debt collectors. ${ }^{11}$

Legally, the method of collection by the lessor accompanied by threats, insults, and terror, as well as the confiscation of goods cannot be justified. This is

\footnotetext{
${ }^{10}$ Soerjono Soekanto, 2010, Pengantar Penelitian Hukum, Universitas Indonesia Press, Jakarta, p. 10. 11 Interview with AKP Rusman Sugianto, SH, Investigator or Officer of the Central Java Police Ditreskrimsus Unit, on 28 June 2021 at 11.00 WIB.
} 
contrary to Act No. 8 of 1999 concerning Consumer Protection. Threats, insults, confiscation of goods and terror are not appropriate dispute resolution efforts.

Forced withdrawals are made to the debtor, both physically and mentally due to the lack of heeding of their wishes (lessor). When the action that has a criminal threat is carried out by the lessor, then there is no word for criminal remission for them, except for certain reasons. The first party should use legal channels, namely through the courts in resolving the problem of default by the second party, so that there is permanent power in confiscation of goods against debtors in the event of bad credit.

\subsection{Constraints on Consumer Protection Against Forced Withdrawals by Leasing Parties in Fiduciary Guarantees}

In practice, the use of Fiduciary Guarantees still has many problems, including those related to the registration of Fiduciary Guarantees, withdrawal of Fiduciary Guarantee objects, the abolition of Fiduciary Guarantees after the debt has been repaid. The obligation to register the Fiduciary Guarantee which has been regulated in the Fiduciary Guarantee Law is a manifestation of the principle of publicity and legal certainty for both creditors and debtors. The problem of withdrawing the object of Fiduciary Guarantee is one of the most common types of problems experienced by consumers. This is due to the withdrawal by the company being carried out without bringing a Fiduciary Guarantee Certificate and involving the debt collector in the vehicle withdrawal process (execution) in which the debt collector does not bring or does not have a power of attorney from the company,

In addition, the issue of eliminating the Fiduciary Guarantee after the debt has been paid off by the debtor is one of the important aspects of consumer protection to protect the Consumer, because if the Fiduciary Guarantee list is not deleted, the Consumer cannot use the object as an object of the Fiduciary Guarantee for further debt agreements or is considered perform a re-fiduciary which is prohibited by the Fiduciary Guarantee Act.

Constraints on consumer protection against forced withdrawals by leasing parties in fiduciary guarantees include:

- Fiduciary Guarantee Registration

The obligation to register for Fiduciary Guarantees has been regulated in the Fiduciary Guarantee Law. The obligation to register Fiduciary Guarantees aims to avoid any re-Fiduciary guarantees that will harm creditors and are prohibited by the Fiduciary Guarantee Law. In addition, the obligation to register a Fiduciary Guarantee is a manifestation of the principle of publicity and legal certainty for both creditors and debtors. At this time the registration of Fiduciary Guarantees has been carried out online as regulated in the Regulation of the Ministry of Law and Human Rights Number 9 of 2013 concerning the Enforcement of Electronic Fiduciary Guarantee Registration. Nevertheless, there are still several obstacles in the registration of Fiduciary Guarantees so that the Financing Company does not register all objects of Fiduciary Guarantees. 
- Guaranteed vehicle withdrawal

The problem of recalling motorized vehicles is one of the most common types of problems experienced by consumers. This is due to the withdrawal by the company being carried out without bringing a Fiduciary Guarantee Certificate and involving debt collectors in the vehicle withdrawal process (execution) in which the debt collector does not bring or does not have a power of attorney from the company, a Fiduciary Guarantee certificate and vehicle withdrawals that are not preceded by the issuance of a letter of attorney. Warning by agreement.

- Elimination of Fiduciary Guarantee after the debt has been repaid

As we know, the Fiduciary Guarantee in the credit agreement is regulated in the accesoir agreement or a follow-up agreement from the main agreement, which means that the birth or loss of the Fiduciary Guarantee depends on whether or not the main agreement is abolished, namely the credit agreement. Thus, if the debt from the Consumer has been repaid, the Financing Company is required to apply for the abolition of the Fiduciary Guarantee against the object being pledged as collateral. ${ }^{12}$

The abolition of the Fiduciary Guarantee is an important part to protect the Consumers, because if the Fiduciary Guarantee is not deleted from the Fiduciary Guarantee list, the Consumer cannot use the object as the object of the Fiduciary Guarantee for further debt agreements or be deemed to have refiduciary which is prohibited by the Fiduciary Guarantee Law.

Based on this, it is necessary to study the existing problems related to the use of Fiduciary Guarantees by Financing Companies by taking into account aspects of consumer protection to increase public trust in the financial services sector and maintain the financial services sector in an accountable and sustainable manner.

\subsection{Consumer Protection Against Forced Withdrawals By Leasing Parties Under Fiduciary Guarantees in the Future}

Consumer Protection is all efforts that guarantee legal certainty to provide protection to consumers. Consumers are every person who uses goods and/or services available in the community, both for the benefit of themselves, their families, other people, and other living creatures and not for trading.

In essence, there are two important legal instruments that form the basis of consumer protection policies in Indonesia, namely: First, the 1945 Constitution, as the source of all sources of law in Indonesia, mandates that national development aims to create a just and prosperous society. The goal of national development is realized through a democratic economic development system so that it is able to grow and develop a world that produces goods and services suitable for consumption by the community. Second, Act No. 8 of 1999 concerning Consumer Protection (UUPK). The enactment of this law provides hope for the Indonesian

\footnotetext{
12 Interview with Aiptu Catur Feski P, SH, Assistant Investigator of the Central Java Police Ditreskrimsus, On June 29, 2021 at 10.00 WIB.
} 
people to obtain protection for losses suffered by transactions of goods and services. UUPK guarantees legal certainty for consumers.

\section{Closing}

The conclusion in this study is that forced withdrawals are made to debtors both physically and mentally due to the lack of heeding of the wishes of the leasing party. When the action that has a criminal threat is carried out by leasing, then there is no word for criminal abolition for them, except for certain reasons. The use of Fiduciary Guarantees still has several obstacles, including: 1). Fiduciary Guarantee Registration. 2). Guaranteed vehicle withdrawals. 3). Elimination of Fiduciary Guarantee after the debt has been repaid. Consumer protection against forced withdrawals in fiduciary guarantees in the future should continue to be consistent with Act No. 8 of 1999 concerning Consumer Protection (UUPK). The birth of this law gives hope to the people of Indonesia, to obtain protection for losses suffered on transactions of goods and services. UUPK guarantees legal certainty for consumers.

Leasing in the withdrawal of motorized vehicles should bring law enforcement officials in this case the police as an assistant to withdraw the debtor's motorized vehicle in order to comply with existing regulations as described in the National Police Chief Number 8 of 2011 concerning Securing the Execution of Fiduciary Guarantees and comply with the procedures established by the National Police, existing laws and regulations so that in the future things do not happen that are not wanted. Debtors (consumers/society) should always carry out their achievements or obligations to creditors so that the financing agreement can run smoothly and safely. The government needs legal counseling to companies or financial institutions in terms of execution of the object of guarantee.

\section{References}

\section{Journal}

[1] Adhe I smail A, "Constitutionalism Concept in Implementation of Indonesian State Administration". Jurnal Daulat Hukum Volume 4 Issue 2, June 2021 ISSN: 2614-560X.

[2] Angga K and Aryani Witasari. "Law Enforcement on Fiducian Security Objects Due to Withdrawal of Fiducia Security Objects". Law Development Journal ISSN : 2747-2604 Volume 3 Issue 1, March 2021.

[3] Ardito, Y P, Umar Ma'ruf and Aryani Witasari. "Implementation of Criminal Action Prosecution Online in Realizing Principle of Fast Prosecution, Simple \& Low Cost", Jurnal Daulat Hukum, Volume 4 Issue 2, June 2021 ISSN: 2614$560 X$.

[4] Feri, S W, and Arpangi. "Settlement Policy of Criminal Actions which Performed by Children through Penal Mediation". Jurnal Daulat Hukum Volume 4 Issue 2, June 2021 ISSN: 2614-560X.

[5] Nurfita A T, Sri Endah Wahyuningsih and Arpangi. "The Police Role in Investigating the Crime of Child Murder as a Result of Infidelity 
Relationships". Law Development Journal ISSN : 2747-2604 Volume 3 Issue 1, March 2021.

\section{Book}

[1] Kelik Pramudya, 2010, Pedoman Etika Profesi Aparat Hukum, Pustaka Yustisia, Jakarta.

[2] Lukman Santoso, 2012, Hukum Perjanjian Kontrak, ed. I, Cakrawala, Yogyakarta.

[3] Soerjono Soekanto, 2010, Pengantar Penelitian Hukum, Universitas Indonesia Press, Jakarta.

[4] Zainal Asikin, 2001, Hukum Kepailitan \& Penundaan Pembayaran Di Indonesia, Raja Grafindo. Jakarta. 